\section{Von Hippel Award Nominations Sought}

\section{The Society's Most Prestigious Honor}

The MRS Awards Committee, cochaired by past president Kathleen $C$. Taylor, has announced that nominations are being accepted for the Society's highest award, the Von Hippel Award of the Materials Research Society. The Award is an international hallmark of excellence in the field of materials research, numbering 11 prominent materials scientists as past recipients.

The Award is named for the Emeritus Professor of the Massachusetts Institute of Technology, Arthur von Hippel, whose laboratory pioneered the collaborative, interdisciplinary research that subsequently has taken the identity of "materials science." The Von Hippel Award recognizes those qualities most prized by materials scientists- brilliance and originality of intellect, combined with vision that transcends conventional scientific disciplines. The Award is presented annually by the Society at its Fall Meeting.

Past recipients of the Award are:

Prof. Arthur von Hippel

Dr. William O. Baker

Prof. David Turnbull

Prof. W. Conyers Herring

Prof. James W. Mayer

Prof. Clarence M. Zener

Prof. Sir Peter B. Hirsch

Dr. Walter L. Brown

Dr. John W. Cahn

Prof. Minko Balkanski

Sir Charles Frank

The recipient is selected by majority vote of the MRS Council from a slate of candidates that is prepared by the Awards Committee. Nominations should be made to the MRS Awards Committee. Names put into nomination are, in accordance with MRS Bylaws, considered active for three years. Nominations must be made using the Von Hippel Award Nomination form obtainable from MRS headquarters and should be accompanied by supporting documentation.

Send nominations to: Kathleen C. Taylor, Physical Chemistry Department, General Motors Research Laboratories, Warren, MI 48090.

\title{
JMR Accepting Papers for Feature Section on Laser and Particle Beam Processing of Materials
}

Joumal of Materials Research will feature a special section of original research papers on laser and particle beam processing of materials in the November/December 1988 issue. This field has been the focus of many symposia at Materials Research Society meetings over the last 10 years. Beginning with "laser annealing," it has evolved into the processing of materials with ion, electron, and laser beams in many different modes and systems.
Chemical as well as physical processes have proved to be of great interest and importance. This special section of $J M R$ will concentrate on the interdisciplinary materials aspects of research in these areas.

Manuscripts for this issue must be received by the IMR Editorial Office by June 1, 1988. They will receive normal but expedited reviews. Accepted articles will be published in the standard Joumal of Materials Research format.
Send manuscripts ( 3 copies plus an original) or inquiries to:

Journal of Materials Research

Materials Research Society

9800 McKnight Road, Suite 327

Pittsburgh, PA 15237

Telephone (412) 367-9111;

$\operatorname{fax}(412) 367-43763$

Please indicate that the manuscript is intended for the Laser and Particle Beam Processing of Materials section of JMR

\section{Materials Research Society Japan Calendar}

Late May 1988 marks the beginning of several weeks of MRS participation in events in Japan focusing on major areas of advanced materials characterization, preparation, and processing.

May 27-30

'88 Advanced Materials \& Engineering Exhibition

Harumi, Tokyo

Over 150,000 people are expected to attend this major exhibition.

$B$ sure to visit the MRS Booth there.

May 30-June 3

First MRS International Meeting on Advanced Materials

See p. 60 in this issue.

June 12-17

Sixth International Conference on Ion Beam Modification of Materials-IBMM ' 88

Sunshine City, Ikebukuro, Tokyo

Cosponsored by the Materials Research Society, Japan Society of Applied Physics, the Okochi Memorial

Foundation.

For information, see the Calendar listing in this issue.

June 13-15

JSAP-MRS International Conference on Electronic Materials-ICEM ' 88

Shigaku-Kaikan Hall, Tokyo

Cosponsored by the Japan Society of Applied Physics and the Materials Research Society in cooperation

with the European Materials Research Society.

For information, see the Calendar listing in this issue. 